\title{
UPAYA PENCEGAHAN PENYAKIT VIRAL NERVOUS NECROSIS PADA YUWANA KERAPU BEBEK (Cromileptes altivelis) MELALUI VAKSINASI
}

\author{
Ketut Mahardika, Isti Koesharyani, dan Tridjoko
}

\begin{abstract}
ABSTRAK
VNN (Viral Nervous Necrosis) merupakan penyakit virus yang dapat menyerang dan menimbulkan kematian massal pada ikan kerapu bebek (C. altivelis). Untuk menghindari hal tersebut, maka diperlukan suatu upaya pencegahan dini terhadap kemungkinan penyebaran penyakit VNN. Tujuan dari penelitian ini adalah mendapatkan metode pencegahan penyakit VNN dengan meningkatkan daya tahan tubuh pada yuwana kerapu bebek melalui vaksinasi. Penelitian ini menggunakan yuwana kerapu bebek berumur 3 bulan dengan jumlah hewan uji masingmasing 100 ekor dan diperlakukan vaksinasi $(0,05 \mathrm{~mL} / \mathrm{ekor}$ secara intramuskular) dan tanpa vaksinasi (kontrol yang diinjeksi dengan posphat buffer saline/PBS). Selanjutnya sebanyak 50 ekor ikan vaksin maupun kontrol ditantang dengan menginfeksikan virus VNN dari konsentrasi $10^{-4}$ dan $10^{-5}$ dan diamati penampakan gejala klinis serta kematian ikan uji selama 2 minggu pemeliharaan. Hasil pengamatan menunjukkan bahwa jumlah (persentase) kematian kelompok ikan kontrol vaksin yang ditantang dengan virus VNN pada konsentrasi $10^{-5}$ yaitu 35 ekor $(70 \%)$ dan konsentrasi $10^{-4}$ yaitu 38 ekor (76\%) lebih tinggi dibandingkan dengan kelompok ikan vaksin yang ditantang dengan virus VNN pada konsentrasi $10^{-5}$ yaitu 3 ekor $(6 \%)$ dan konsentrasi $10^{-4}$ yaitu 5 ekor (10\%). Analisis deteksi VNN dengan PCR menunjukkan bahwa ikan-ikan yang masih hidup pada kelompok kontrol (tanpa vaksin) dan ditantang dengan virus VNN pada konsentrasi $10^{-5}$ ternyata $90 \%$ terinfeksi VNN, dan pada konsentrasi $10^{-4}$ ternyata $100 \%$ positif terinfeksi VNN. Sedangkan pada kelompok ikan vaksin ternyata $100 \%$ negatif terinfeksi VNN. Secara histopatologi gambaran retina mata ikan yang terserang (positif) VNN menampakkan adanya nekrosis dan vakuolasi, sedangkan ikan yang sehat retina matanya tampak normal. Hasil tersebut menunjukkan bahwa permberian vaksin (inaktif vaksin dengan 0,5\% formalin secara intramuskular) pada yuwana kerapu bebek dapat mencegah atau mengurangi kematian ikan akibat serangan VNN.
\end{abstract}

ABSTRACT: Prevention method for viral nervous necrosis of the humpback grouper (C. altivelis) juvenile through vaccination. By: Ketut Mahardika, Isti Koesharyani, and Tridjoko

VNN (viral nervous necrosis) is a viral disease infects and causes mass mortality of humpback grouper (C. altivelis). To avoid this, prevention method was carried out to protect possible spread of this disease. The purpose of their was study to obtain prevention method of VNN disease through vaccination to increase the body immunity of humpback grouper juvenile. This study used of 100 juveniles of \pm 3-month old, which were given vaccination (injected by $0.5 \mathrm{~mL} /$ fish intramuscularly) and control/without vaccination (injected by PBS) and reared for 10 days. Furthermore, each of 50 vaccinated fish and control were challenged with VNN viral concentration of $10^{-4}$ and $10^{-5}$. Clinical signs and mortality of test fish were observed for 2 weeks. Total mortality of control groups challenged with VNN viral concentration of $10^{-5}$ was 35 fishes (70\%) while at VNN concentration of $10^{-4}$ is 38 fishes (76\%). These mortalities were higher than fish of vaccination groups challenged with VNN viral concentration of $10^{-5}$ ( 3 fishes or $6 \%$ ) and with VNN concentration of $10^{-4}$ (5 fishes or $\left.10 \%\right)$. The VNN viral detection by PCR showed that fish of the control groups challenged with VNN viral concentration of $10^{-5}$ and $10^{-4}$ were $67 \%$ and $100 \%$ positively infected by VNN, respectively. From vaccination groups challenged with VNN viral concentration of $10^{-5}$ and $10^{-4}$, each 10 fish obviously $100 \%$ uninfected. Histopathologically, necrosis, and vacuolation in the retina eyes were observed positively infected of VNN fish, while normal retina were observed from health fish. This result revealed that vaccination (inactivated vaccine with $0.5 \%$ formalin through intramuscularly) of the humpback grouper juvenile could prevent or decrease fish mortality caused by VNN disease.

KEYWORDS: VNN, Cromileptes altivelis, vaccination, inactivated vaccine, intramuscularly 


\section{PENDAHULUAN}

Perbenihan ikan kerapu bebek (Cromileptes altivelis) telah berhasil dilakukan di Balai Besar Riset Perikanan Budidaya Laut Gondol, Bali, beberapa tahun yang lalu. Tetapi dalam perkembangannya masih dihadapkan pada beberapa masalah, di antaranya adalah penyakit yang disebabkan oleh virus. Penyakit virus yang sering menimbulkan kematian massal pada larva dan yuwana kerapu bebek adalah viral nervous necrosis (VNN) (Koesharyani et al., 1999; Zafran et al., 2000). Kejadian VNN ini sering ditemukan pada larva dan yuwana yang dipelihara di panti benih maupun yuwana yang dipelihara di jaring apung.

VNN menyerang berbagai spesies ikan laut seperti Japanese parrotfish, Oplegnathus fasciatus (Yoshikoshi \& Inoue, 1990); seabass, Dicentrarchus labrax (Breuil et al., 1991); redspotted grouper, E. akaara (Mori et al., 1991); striped jack, Pseudocaranx dentex (Mori et al., 1992); barramundi, Lates calcarifer (Glazebrook et al., 1990; Renault et al., 1991; Munday et al., 1992; Munday \& Owens, 1988); dan barfin flounder, Verasper moseri (Watanabe et al., 1998). Di Indonesia, kejadian VNN pertama dilaporkan tahun 1997 pada ikan kakap putih, Lates calcarifer (Zafran et al., 1998). Selain menyerang ikan kerapu bebek, VNN juga menyerang ikan kerapu batik (E. polyphekadion), kerapu macan (E. microdon), dan kerapu lumpur ( $E$. coioides) (Koesharyani et al., 2001).

VNN disebabkan oleh nodavirus (famili dari Nodaviridae). Pada ikan yang terserang VNN akan tampak gejala tidak normal seperti terlihat lemah berkelompok di dasar atau berenang dengan gerakan tidak terarah serta nafsu makan menurun secara drastis, kemudian ikan-ikan tersebut mati dan dapat menularkan virus kepada ikan lainnya (Koesharyani et al., 1999). Pengamatan secara histopatologi, terlihat adanya vacuolasi pada otak dan retina mata, sedangkan ukuran partikel virus ini berdiameter antara 25-34 nm dengan bentuk isokohedral non enpeloped (Mori et al., 1992). Adanya VNN pada ikan dapat dideteksi dengan cepat menggunakan metode Polymerase Chain Reaction (PCR) (Nishizawa et al., 1994).

Salah satu upaya pencegahan terhadap penyakit virus adalah dengan melakukan vaksinasi. Vaksinasi merupakan usaha untuk meningkatkan kekebalan tubuh terhadap suatu penyakit dengan cara memberikan atau memasukkan bibit penyakit (patogen) yang telah dilemahkan atau dimatikan yang nantinya diharapkan dapat merangsang tubuh untuk memberikan respon kekebalan terhadap suatu penyakit yang sama. Secara umum terdapat 2 tipe vaksin yaitu vaksin mati yang berupa ekstrak organisme patogen dan vaksin hidup yang berupa organisme patogen yang dilemahkan tanpa atau dengan mengurangi virulensinya (Eliss, 1988). Pencegahan penyakit virus dengan vaksinasi menggunakan vaksin inaktif pernah dilakukan terhadap Infektious Pancreatic Necrosis (IPN) pada ikan rainbow trout dengan sintasan mencapai $98 \%$ setelah uji tantang (Dorson, 1988); Viral Haemorrhagic Septicaemia (VHS) terhadap ikan rainbow trout dengan sintasan $39 \%-58 \%$ setelah uji tantang (Kinkelin, 1988), red sea bream iridovirus disease (RSIVD) pada ikan red sea bream dengan sintasan mencapai $80 \%-100 \%$ setelah uji tantang (Nakajima et al., 1997). Adapun tujuan dari penelitian ini adalah untuk mendapatkan metode pencegahan penyakit VNN dengan meningkatkan daya tahan tubuh yuwana kerapu bebek melalui vaksinasi.

\section{BAHAN DAN METODE}

\section{Ikan Uji}

Ikan uji yang digunakan dalam penelitian ini adalah 200 ekor yuwana kerapu bebek sehat umur 3 bulan dengan rata-rata bobot badan $3,49 \pm 0,75$; panjang total $65,6 \pm 5,21$; dan panjang tubuh $53,6 \pm 4,7$. I kan uji tersebut diaklimatisasi dalam bak fiber $500 \mathrm{~L}$ selama seminggu.

\section{Pembuatan Vaksin dan Inokulum Virus untuk Uji Tantang}

Yuwana kerapu bebek umur 3 bulan yang terserang VNN secara alami diambil bagian mata dan otaknya sebanyak $20 \mathrm{~g}$, kemudian digerus dan ditambahkan $200 \mathrm{~mL}$ larutan $10 \mathrm{mM}$ phosphate buffer saline (PBS) $\mathrm{pH} 7,2$; selanjutnya disentrifugasi $3.000 \mathrm{rpm}$ selama 30 menit; supernatannya disaring dengan membran filter $(0,45 \mathrm{~mm})$; dan digunakan sebagai sumber inokulum untuk uji tantang (Arimoto et al., 1993). Sedangkan vaksin dibuat dari inokulum yuwana kerapu bebek umur 34 hari dengan prosedur seperti di atas dan inokulum virus tersebut dibuat tidak aktif (inactive virus) dengan $0,5 \%$ formalin. Selanjutnya disimpan dalam kulkas (suhu $4^{\circ} \mathrm{C}$ ) selama 10 hari. Sebelum digunakan sebagai vaksin inokulum virus tersebut diujikan pada 10 ekor yuwana kerapu bebek dengan konsentrasi 0,05 mL/ekor dan diamati selama 2 minggu pemeliharaan.

\section{Perlakuan}

Dua kelompok ikan uji, masing-masing 100 ekor yuwana kerapu bebek diberi perlakuan vaksinasi dan tanpa vaksinasi (kontrol). Vaksin diberikan dengan penyuntikan sebanyak $0,05 \mathrm{~mL} /$ ekor secara intramuskular, sedangkan pada kontrol penyuntikan dengan larutan $10 \mathrm{mM}$ phosphate buffer saline (PBS) $\mathrm{pH} 7,2$ sebanyak $0,05 \mathrm{~mL} /$ ekor secara intramuskular. 
Setelah 10 hari pemeliharaan dilakukan uji tantang pada masing-masing 50 ekor ikan uji dari kelompok vaksinasi dan kontrol dengan 2 konsentrasi virus VNN $\left(10^{-4}\right.$ dan $\left.10^{-5}\right)$ sebanyak $0,05 \mathrm{~mL} /$ ekor secara intramuskular, kemudian diamati selama dua minggu pemeliharaan. Pengamatan dilakukan selama 14 hari (2 minggu) terhadap kematian yuwana, gejala klinis, deteksi dengan Polymerase Chain Reaction (PCR), dan pengamatan histopatologi. Analisis data dilakukan secara deskriptif.

Mata dan otak dari ikan-ikan uji yang mati dan yang masih hidup pada sampling terakhir, masingmasing dimasukkan ke dalam eppendorf steril dengan gunting dan pinset steril berbeda serta digunakan untuk mendeteksi virus dengan teknik RT-PCR ( $R e$ verse Transcription-Polymerase Chain Reaction). Ekstraksi RNA menggunakan isogen (Iwamoto et al., 1999). Aplikasi atau penggandaan DNA VNN menggunakan universal primer yaitu F2 (CgTgTCAgTCATgTgTCgCT) dan R3 (CgAgTCAACACgggTgAAgA), primer tersebut merupakan hasil sekuensing dari Striped Jack Nervous Necrosis Virus (SJNNV), pada T-4 dengan target molekul 426 bp. (Nishizawa et al., 1994). Hasil amplifikasi RT-PCR selanjutnya dielektroforesis pada $1,5 \%$ agarose gel selama 25 menit dalam TAE buffer dan diwarnai dengan Ethidium bromida selama 10-15 menit. Pembacaan hasil dilakukan dengan UV transilluminator dan difoto sebagai dokumentasi menggunakan polaroid gel kamera. Teknik deteksi
VNN dengan RT-PCR yang dilakukan di BBRPBL, Gondol-Bali telah dimodifikasi sedemikian rupa, sehingga mudah dalam pengerjaannya (Yuasa et al., 2001).

Sedangkan ikan-ikan uji yang moribund dan yang sehat sesudah dua minggu diinfeksi (sampling terakhir) diambil salah satu bagian matanya. Setelah difiksasi dalam 10\% buffer formalin dan didekalsifikasi dalam $5 \%$ asam formiat, selanjutnya diproses berdasarkan metode Gunarso (1989) yang telah dimodifikasi. Kemudian semua sampel ditanam dalam parafin dan dipotong dengan ketebalan 3-5 mm serta diwarnai dengan haematoxylin-eosin (H\&E), selanjutnya diamati di bawah mikroskop dengan pembesaran 20X-40X.

\section{HASIL DAN BAHASAN}

Uji patogenisitas dari inokulum yang digunakan untuk vaksin terhadap 10 ekor yuwana kerapu bebek, gejala moribund terlihat mulai hari ke-3 setelah infeksi, dan selama 2 minggu pemeliharaan terdapat 7 ekor ikan yang mati dan 3 ekor mengalami pemulihan kesehatan.

Gejala klinis seperti berenang tanpa arah atau diam di dasar air terlihat mulai hari ke-3 setelah infeksi (post infection/pi). Gejala tersebut sama dengan kejadian VNN pada larva seabass, Lates calcarifer (Zafran et al., 1998). Kematian ikan mulai terjadi pada hari ke-3 dan jumlah kematian ikan uji banyak terjadi pada

Tabel 1. Jumlah kematian ikan yuwana kerapu bebek (C. altivelis) selama 2 minggu pemeliharaan setelah dilakukan uji tantang dengan virus VNN pada konsentrasi $10^{-5}$ dan $10^{-4}$ pada masing-masing 50 ekor ikan uji (kontrol maupun vaksinasi)

Table 1. Total mortality of humpback grouper juvenile (C. altivelis) for 2 weeks after used challenge test with VNN viral concentration of $10^{-5}$ and $10^{-4}$ of each 50 fish test (control and vaccination)

\begin{tabular}{|c|c|c|c|c|c|c|c|c|c|c|c|c|c|c|c|}
\hline \multirow{2}{*}{$\begin{array}{l}\text { Perlakuan } \\
\text { Treatment }\end{array}$} & \multicolumn{14}{|c|}{$\begin{array}{c}\text { Kematian yuwana kerapu bebek/hari selama } 2 \text { minggu } \\
\text { Mortality of humpback grouper/days for } 2 \text { weeks }\end{array}$} & \multirow{2}{*}{$\begin{array}{c}\text { Persentase } \\
\text { kematian } \\
\text { Percentage } \\
\text { mortality }\end{array}$} \\
\hline & 1 & 2 & 3 & 4 & 5 & 6 & 7 & 8 & 9 & 10 & 11 & 12 & 13 & 14 & \\
\hline $\mathrm{K}-1$ & 0 & 0 & 3 & 6 & 3 & 12 & 4 & 3 & 1 & 1 & 2 & 0 & 0 & 0 & $70 \%$ \\
\hline K-2 & 0 & 0 & 3 & 3 & 10 & 13 & 3 & 3 & 2 & 0 & 1 & 0 & 0 & 0 & $76 \%$ \\
\hline$V-1$ & 0 & 0 & 0 & 0 & 2 & 1 & 0 & 0 & 0 & 0 & 0 & 0 & 0 & 0 & $6 \%$ \\
\hline$V-2$ & 0 & 0 & 1 & 1 & 0 & 0 & 0 & 2 & 0 & 1 & 0 & 0 & 0 & 0 & $10 \%$ \\
\hline
\end{tabular}

$\mathrm{K}-1=$ Kelompok kontrol vaksin dari yuwana kerapu bebek yang ditantang dengan virus VNN konsentrasi $10^{-5}$ (Vaccine control groups of juvenile humpback grouper and challenged with VNN concentration of $10^{-5}$ )

$\mathrm{K}-2=$ Kelompok kontrol vaksin dari yuwana kerapu bebek yang ditantang dengan virus VNN konsentrasi $10^{-4}$ (Vacinne control groups of juvenile humpback grouper and challenged with VNN concentration of $10^{-4}$ )

$\mathrm{V}-1=$ Kelompok vaksin dari yuwana kerapu bebek yang ditantang dengan virus VNN konsentrasi $10^{-5}$ (Vaccination groups of juvenile humpback grouper and challenged with VNN concentration of $10^{-5}$ )

$\mathrm{V}-2=$ Kelompok vaksin dari yuwana kerapu bebek yang ditantang dengan virus VNN konsentrasi $10^{-4}$ (Vaccination groups of juvenile humpback grouper and challenged with VNN concentration of $10^{-4}$ ) 
minggu pertama dan kematian ikan terhenti pada hari ke-12 setelah infeksi (Tabel 1), meskipun ikan yang menunjukkan gejala klinis seperti di atas masih terlihat sampai hari ke-14 pada kelompok ikan kontrol (tanpa vaksinasi), sedangkan kelompok ikan vaksin sampai hari ke-14 tidak ada yang menunjukkan gejala klinis. Total kematian ikan antara kelompok kontrol yang ditantang dengan virus VNN $10^{-5}$ yaitu 35 ekor (70\%) tidak berbeda dengan kelompok kontrol yang vaksinasi maupun kontrol yang mati setelah ditantang dengan virus VNN ternyata positif terinfeksi VNN. Ini ditandai dengan penampakan pita tunggal dengan berat molekul 426 bp pada agarose gel (Gambar 1). Adanya ikan yang mengalami vaksinasi dan yang positif terinfeksi VNN kemungkinan disebabkan oleh kondisi ikan yang lemah setelah pemberian vaksin, vaksin tidak masuk ke dalam tubuh ikan atau ikan menjadi stress dengan perlakuan tersebut. Akan

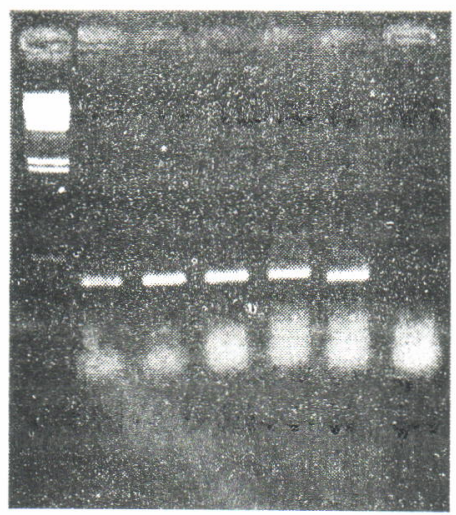

Gambar 1. Gel Agarose Electrophoresis RT-PCR hasil amplifikasi dari yuwana kerapu bebek, C. altivelis yang mati setelah dilakukan uji tantang dengan virus VNN. 1: Marker (I Hind III); 2: Kontrol (VNN 10-5); 3: Kontrol (VNN 10-4); 4: Vaksin (VNN 10-5); 5: Vaksin (VNN 10-4); 6: Positif kontrol; 7: Negatif kontrol

Figure 1. Agarose gel electrophoresis of RT-PCR amplification product from died fish of humpback groupers, C. altivelis after challenged test with VNN viral. Line 1: Marker (( Hind III); 2: Control (VNN 10-5); 3: Control (VNN 10-4); 4: Vaccine (VNN 10-5); 5: Vaccine (VNN 10-4); 6: Positive control; 7: Negative control

ditantang dengan virus VNN $10^{-4}$ yaitu 38 ekor $(76 \%)$ Hal yang sama terlihat pula pada mortalitas antara kelompok vaksin yang ditantang dengan virus VNN $10^{-5}$ yaitu 3 ekor $(6 \%)$ dengan kelompok vaksin yang ditantang dengan virus VNN $10^{-4}$ yaitu 5 ekor (10\%). Sedangkan total kematian kelompok ikan kontrol sangat nyata lebih tinggi daripada kelompok ikan yang mendapatkan vaksinasi.

Ikan-ikan yang mati setelah dilakukan uji tantang dengan VNN selanjutnya dideteksi dengan PCR menggunakan primer spesifik. Ikan-ikan perlakuan tetapi kematian ikan yang mendapatkan vaksinasi relatif kecil (6\%-10\%) dibandingkan dengan ikan kontrol (70\%-76\%), ini menunjukkan bahwa dengan pemberian vaksin mampu menekan kematian ikan akibat serangan VNN.

Pada sisa ikan kontrol yang ditantang dengan virus VNN $10^{-5}$ sebanyak 15 ekor dan ikan kontrol yang ditantang dengan virus VNN $10^{-4}$ sebanyak 12 ekor, serta masing-masing 10 ekor kelompok ikan vaksin yang ditantang dengan virus VNN $10^{-5}$ dan VNN $10^{-4}$ diambil secara acak dan dideteksi VNN (Tabel 2). Dari

Tabel 2. Hasil deteksi RT-PCR pada ikan uji yang masih hidup pada sampling akhir penelitian

Table 2. Detection RT-PCR results of the fish test were still life of finished sampling treatment

\begin{tabular}{ccccc}
\hline & & Hasil Uji RT-PCR & Persentase total ikan \\
Treatment & $\begin{array}{c}\text { Jumlah ikan uji } \\
\text { Total fish test }\end{array}$ & $\begin{array}{c}\text { Positif } \\
\text { Positive }\end{array}$ & $\begin{array}{c}\text { Negatif } \\
\text { Negative }\end{array}$ & $\begin{array}{c}\text { yang terinfeksi } \\
\text { Percent total infected } \\
\text { fish }\end{array}$ \\
\hline K-1 & 15 ekor (individu) & 10 ekor (individu) & 5 ekor (individu) & $90 \%$ \\
K-2 & 12 ekor (individu) & 12 ekor (individu) & 0 & $100 \%$ \\
V-1 & 10 ekor (individu) & 0 & 10 ekor (individu) & $0 \%$ \\
V-2 & 10 ekor (individu) & 0 & 10 ekor (individu) & $0 \%$ \\
\hline
\end{tabular}


15 ekor ikan yang masih hidup setelah uji tantang dengan VNN konsentrasi $10^{-5}$ ternyata 10 ekor positif terinfeksi VNN dan 5 ekor negatif terinfeksi VNN ( $90 \%$ positif VNN), dan dari 12 ekor ikan yang masih hidup setelah uji tantang dengan VNN konsentrasi $10^{-4}$ ternyata 12 ekor positif terinfeksi VNN (100\% positif VNN). Hal tersebut menunjukkan bahwa virus VNN yang diisolasi dari yuwana kerapu bebek dengan konsentrasi $10^{-4}$ dan $10^{-5}$ masih sangat berbahaya bagi yuwana kerapu bebek karena masih menyebabkan kematian massal yang mencapai $70 \%-76 \%$, terlihat bahwa dari masing-masing 10 ekor ikan hidup yang diambil secara acak tidak menunjukkan adanya serangan VNN (100\% negatif VNN), hal ini juga diperkuat dengan gambaran histologi dari retina mata yang terlihat normal (Gambar 2B). Vaksinasi melalui

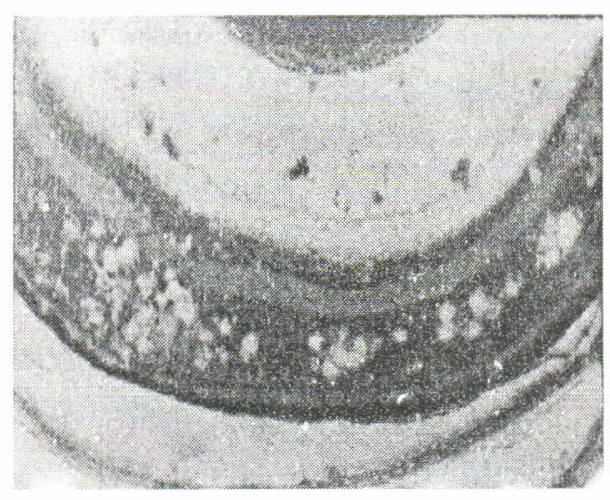

al., 1992; Arimoto et al., 1993; Zafran et al., 1998; Zafran et al., 2000; Bloch et al., 1991; Boonyaratpalin et al., 1996; Chua et al., 1995). Sedangkan pengamatan dengan elektron mikroskop yang dilakukan pada kakap putih, L. calcarifer yang terserang VNN di Indonesia dapat dilihat adanya partikel virus yang berdiameter $30 \mathrm{~nm}$ (Zafran et al., 1998).

\section{KESIMPULAN}

Dari hasil penelitian ini dapat disimpulkan bahwa vaksinasi menggunakan inaktif vaksin (virus VNN dimatikan dengan $0,5 \%$ formalin) secara intramuskular terhadap infeksi virus VNN konsentrasi $10^{-4}$ dan $10^{-5}$ dapat mengurangi atau menekan mortalitas $(90 \%-$ $94 \%$ ) yuwana kerapu bebek, C. altivelis.

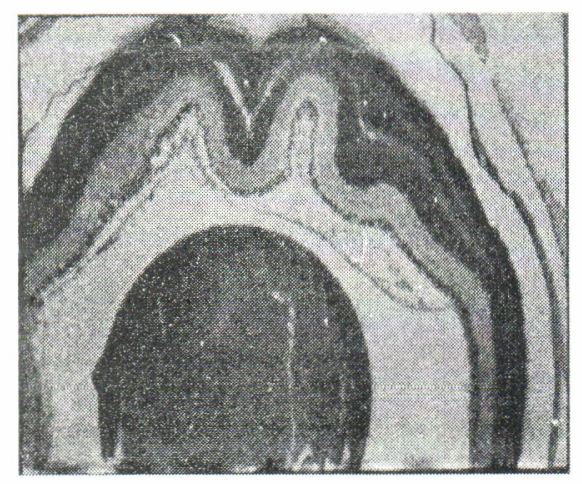

Gambar 4. A). Retina mata yuwana kerapu bebek kelompok kontrol yang terserang VNN dengan vakuolasinya (tanda panah). B). Retina mata normal dari kelompok vaksin (pewarnan H\&E, 20X)

Figure 4. A). Cross section of retina eye of control group's juvenile humpback grouper after being infected

penyuntikan efektif dalam menekan kematian ikan akibat serangan VNN. Hal ini disebabkan karena pemberian vaksin dapat memacu sistem kekebalan tubuh ikan untuk membentuk antibodi spesifik dan akan menjadi sel-sel memori dalam jangka waktu tertentu. Selain metode di atas terdapat metode lain dalam melakukan vaksinasi ikan yaitu metode immersi (immersion methods), pencelupan (dip vaccination), perendaman (bath vaccination), pakan (oral vaccination), dan vaksinasi automatis (automatic of vaccination). Namun di antara metode tersebut vaksinasi melalui injeksi menunjukkan hasil yang lebih baik, akan tetapi metode ini hanya dapat diterapkan pada yuwana sampai induk ikan, sedangkan pada stadia larva tidak mungkin diterapkan (Eliss, 1988).

Secara histologi tampak adanya necrosis dan vakuolasi pada retina mata (gambar $2 \mathrm{~A}$ ) dari kelompok ikan kontrol vaksin yang positif terinfeksi VNN. Indikasi kerusakan jaringan pada kerapu bebek ini ternyata sama dengan kerusakan yang terjadi pada kasus serangan VNN pada ikan budi daya lainnya (Munday \& Owen, 1988; Glazebrook et al., 1990; Munday et

\section{SARAN}

Metode vaksinasi secara intramuskular hanya dapat diaplikasikan pada ikan stadia yuwana sampai induk. Oleh karena itu, diperlukan adanya penelitian vaksinasi lanjutan dengan metode perendaman atau oral terhadap larva kerapu bebek, C. altivelis dan ikan kerapu lainnya.

\section{DAFTAR PUSTAKA}

Arimoto, M., K. Mori, T. Nakai, K. Muroga, and I. Furusawa. 1993. Pathogenicity of the causative agent of viral nervous necrosis disease in striped jack, Pseudocaranx dentex (Bloch and Schneider). J. Fish Disease. 16: 461--469.

Bloch, B., K. Gravningen and J.L. Larsen. 1991. Encephalomyelitis among turbot associated with apicornavirus-like agent. Diseases of Aquatic Organism. 10: 65--70.

Boonyaratpalin, S., K. Supamattaya, J. Kasornchandra, and H.R. Hoffman. 1996. Picorna-like virus associated with mortality and spongious encephalopathy in grouper Epinephelus malabaricus. Diseases of Aquatic Organism. 26: 75--80. 
Breuil,G., J.R. Bonami, J.F. Pepin, and Y. Pichot. 1991. Viral infection (Picorna-like virus) associated with mass mortalities in hatchery-reared sea-bass (Dicentrarchus labrax) larvae and juvenile. Aquaculture. 97: 109--116.

Chua, F.H.C., J.J. Loo, and J.Y. Wee. 1995. Mass mortality in juvenile grasy grouper, Epinephelus tauvina, associated with vacuolating encephalopathy and retinopathy. Diseases in Asian Aquaculture. p. 253-241

Dorson, M. 1988. Vaccination against infectious pancreatic necrosis virus. In Fish Vaccination Eliss (Eds.) Academic Press Limited, London. p. 162--171.

Eliss, A.E. 1988. Fish Vaccination. Academic Press Limited, London. p. 461--469.

Glazebrook, J.S., M.P. Heasman, and S.W. de Beer. 1990. Picorna-like viral particles associated with mass mortalities in larval barramundi, Lates calcarifer Bloch. Journal of Fish Diseases. 13: 245--249.

Gunarso, W. 1989. Mikroteknik. Departemen Pendidikan dan Kebudayaan, Direktorat Jenderal Pendidikan Tinggi. Pusat Antar Universitas IImu Hayat Institut Pertanian Bogor.

Iwamoto, T., K. Mori, M. Arimoto, T. Nakai. 1999. High permisivity of the fish cell line SSN-1 for Piscine nodaviruses. Dis. Aquat. Organism. 39: 37--47.

Kinkelin, P. 1988. Vaccination against viral haemorrhagic septicaemia. In Fish Vaccination. Ellis (Eds.) Academic Press Limited, London. p. 172--191.

Koesharyani, K., Zafran, dan K. Yuasa. 1999. Deteksi viral nervous necrosis (VNN) menggunakan polymerase chain reaction (PCR) pada ikan kerapu bebek, Cromileptes altivelis. Prosiding Seminar Nasional Penelitian dan Diseminasi Teknologi Budidaya Laut dan Pantai, Jakarta. p. 237--240.

Koesharyani, I., D. Roza, K. Mahardika, F. Johnny, Zafran, and K. Yuasa. 2001. Manual for Fish Disease Diagnosis-11. Research Institute for Mariculture, Central Research Institute for Fisheries and Japan International Cooperation Agency. 48 pp.

Mori, K., T. Nakai, M. Nagahara, K. Muroga, T. Mekuchi, and T. Kanno. 1991. A viral diseases in hatcheryreared larvae and juvenile of red spotted grouper. Gyobyo Kenkyu. 26(4): 206--210.

Mori K., T. Nakai, K. Muroga, M. Arimoto, K. Mushiake, and I. Furusawa. 1992. Properties of new virus be- longing to Nodaviridae found in larval striped jack (Pseudocaranx dentex) with nervous necrosis. Viro/ogy. 187: 368--371

Munday, B.L., J.S. Langdon, A. Hyatt, and J.D. Humphrey. 1992. Mass mortality associated with a viral-induced vacuolating encephalopathy and retinopathy of larval and juvenile barramundi, Lates calcarifer Bloch. Aquaculture. 103: 197--211.

Munday, B.L. and L. Owens. 1988. Viral disease of fish and sellfish in Australian mariculture. Fish Pathology. 33(4): 193--200

Nakajima K., Y. Maeno, J. Kurita, and Y. Inui. 1997. Vaccination against red sea bream iridoviral disease in red sea bream. Fish Pathology. 32(4): 205-209.

Nishizawa, T., K.I. Mori, T. Nakai, I. Furusawa, and K. Muroga. 1994. Polymerase Chain Reaction (PCR) amplification of RNA of Striped Jack Viral Nervous Necrosis (SJVNN). Diseases of Aquatic Organism. 18: $\uparrow 03--107$

Renault, T., P. Haffner, B. Laurencin, F.G. Breuil and J.R. Bonami. 1991. Mass mortalities in hatchery-reared sea bass (Lates calcarifer) larvae associated with the presence in the brain and retina of virus like particles. Bull. Eur. Ass. Fish Pathol. 11(2): 68.

Watanabe K., S. Suzuki, K. Suzuki, T. Nishizawa, M. Yoshimizu, and Y. Ezura. 1998. Control strategy for viral nervous necrosis of barfin flounder. Fish Pathology. 33(4): 445--446

Yoshikoshi, K. and K. inoue. 1990. Viral nervous necrosis in hatchery-reared larvae and juveniles of japanese parotfish, Oplegnathus fasciatus (Temminck and Schlegel). Joumal of Fish Diseases. 13: $69--77$

Yuasa, K., i. Koesharyani, D. Roza, K. Mahardika, F. Johnny, and Zafran. 2001. Manual for PCR Procedure : Rapid diagnosis on Viral Nervous Necrosis (VNN) in grouper. Lolitkanta-JICA Booklet. p. 13--35.

Zafran, T. Harada, I. Koesharyani, K. Yuasa, and K. Hatai (1998). Indonesian hatchery reared sea bass larvae (Lates calcarifer), associated with viral nervous necrosis (VNN). IFR Journal. IV(I): 19--22.

Zafran, I. Koesharyani, F. Johnny, K. Yuasa, T. Harada, and K. Hatai. 2000. Viral nervous necrosis in humpback grouper Cromileptes altivelis larvae and juveniles in Indonesia. Fish Pathology. 35 (2): 95--96. 